\title{
症例報告
}

\section{Kasabach-Merritt 症候群}

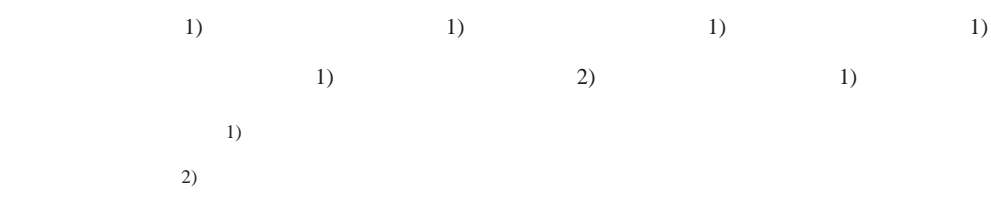

\section{Kasabach-Merritt Syndrome}

Tomoko KIDA ${ }^{1)}$, Hiroyuki Shichino ${ }^{1)}$, Motoaki $\mathrm{CHIN}^{1)}$, Nobuhiko NAGANO ${ }^{1)}$, Naohiro Ryo ${ }^{1)}$, Tsutomu SAITO ${ }^{2)}$ and Hideo Mugishima ${ }^{1)}$

${ }^{1)}$ Department of Pediatrics and Child Health, Nihon University School of Medicine

${ }^{2)}$ Department of Radiological Oncology, Nihon University School of Medicine

We report our experiences with two infants with Kasabach-Merritt syndrome. The first case exhibited a hemangioma in his right shoulder. We treated him with corticosteroids, radiation therapy, and interferon alpha. After treatment with interferon alpha was initiated, the size of the hemangioma decreased and his platelet counts and other markers of coagulation returned to the normal range. However, since afebrile convulsion occurred after 8 weeks of interferon treatment, we decreased that treatment thereafter. The second case exhibited a hemangioma in his left arm, and we treated him with corticosteroid and radiation therapy. After the initiation of radiation therapy, the size of the hemangioma decreased and his platelet counts returned to the normal range. Neither patient has experienced recurrence. These cases support the notion that the proper treatment must be selected in a step-by-step manner, based on the status of each individual patient and on the balance between the efficacy and adverse effects of treatment.

Key words: Kasabach-Merritt syndrome, hemangioma, radiation therapy, interferon-alpha カサバッハメリット症候群 , プレドニゾロン療法 , 放射線療法 , インターフェロン $\alpha$

(J. Nihon Univ. Med. Ass., 2009; 68 (6): 339-342)

要旨カサバッハメリット症候群の 2 乳児例を経験し た . 症例 1 はプレドニゾロン (PSL) 療法と放射線療法を 選択したが, 血小板数の改善なく INF- $\alpha$ 療法を開始し た、治療効果がみられたが, 無熱性痙攣を認め中止し た . 症例 2 は PSL 療法にて効果がみられず放射線療法 を選択した . 終了後より改善がみられた . 両症例とも現 在まで再燃や晚期障害はない，今回経験した 2 例では PSL 療法を開始し, 兴の後各種治療法から適切であると 考える治療法を選択した。

\section{I. 背 景}

カサバッハメリット症候群は巨大血管腫に血小板減少 と凝固線溶系の異常を合併する病態であり，しばしば多 量の出血を認めたり，動静脈シャントによる心不全を認 めたりして管理に難渋する事がある . 死亡率 10-37\%と 推定されている. 現在いくつかの治療法か蕔告されてい るがいまだに確立された治療法はない, 我々は多量の出 血を認めたカサバッハメリット症候群の 2 乳児例を経験 し，プレドニゾロン $(\mathrm{PSL})$ 療法と放射線療法あるいはイ ンターフェロン $\alpha(\mathrm{IFN}-\alpha)$ 療法を選択し軽快した症例を 経験したので報告する .

\section{II. 症例}

症例 $1: 1$ か月, 男児

主 訴: 右背部腫瘤

家族歴・妊娠分婏歴 : 特記事項なし

現病歴 : 出生後から認めていた右肩の腫瘤が次第に増 大し暗紫色になった . 1 か月健診で血管腫を指摘され当 院へ入院した .

入院時身体所見：全身状態は良好.身長 $54 \mathrm{~cm}$,体重 $4502 \mathrm{~g}$, 体温 $36.9^{\circ} \mathrm{C}$, 呼吸数 38 回/分, 心拍整 130 回/ 分, 収縮期血圧 $90 \mathrm{mmHg}$. 大泉門平坦, 全身色蒼白, 眼瞼結膜貧血あり，咽頭口腔内出血なし，光の他の身体 所見に異常は認めなかった . 右背部に $9 \times 9 \mathrm{~cm}$ の弾性 硬で波動を触れない暗紫色の腫瘤を認める.

入院時検査所見 (Table 1)：血液検査では貧血および著 明な血小板減少を認めた，凝固検査ではフィブリノーゲ ン (Fib) の低下, FDP の上昇があり，凝固線溶系の異常 が認められた 。

CT 画像 (Fig. 1) : 右背部に腫瘤像を認め，肩甲骨下に も腫瘤が入り込んでいる.最大径は $5 \times 7 \mathrm{~cm}$ で内部は 不均一に造影され，周囲組織との境界は不明瞭であった . 
Table 1 Laboratory data

Case 1.

\begin{tabular}{|c|c|c|c|}
\hline \multicolumn{2}{|c|}{ Peripheral blood } & \multicolumn{2}{|c|}{ Blood chemistry } \\
\hline WBC & $10400 / \mu l$ & T.Bil & $10.63 \mathrm{mg} / \mathrm{d} l$ \\
\hline Myelo & + & D.Bil & $0.54 \mathrm{mg} / \mathrm{d} l$ \\
\hline Band & $1.5 \%$ & AST & $22 \mathrm{U} / \mathrm{l}$ \\
\hline Seg & $22.5 \%$ & ALT & $9 \mathrm{U} / \mathrm{l}$ \\
\hline Eo & $1 \%$ & LDH & $374 \mathrm{U} / l$ \\
\hline Мo & $8.5 \%$ & BUN & $14.3 \mathrm{mg} / \mathrm{d} l$ \\
\hline Ly & $66 \%$ & $\mathrm{Cr}$ & $0.22 \mathrm{mg} / \mathrm{d} l$ \\
\hline $\mathrm{RBC}$ & $2.29 \times 10^{4} / \mu l$ & $\mathrm{Na}$ & $142 \mathrm{mEq} / \mathrm{l}$ \\
\hline $\mathrm{Hb}$ & $7.3 \mathrm{~g} / \mathrm{d} l$ & $\mathrm{~K}$ & $4.8 \mathrm{mEq} / \mathrm{l}$ \\
\hline $\mathrm{Ht}$ & $21.7 \%$ & $\mathrm{Cl}$ & $107 \mathrm{mEq} / \mathrm{l}$ \\
\hline $\mathrm{MCV}$ & $92.3 \mathrm{fl}$ & $\mathrm{Ca}$ & $10.3 \mathrm{mg} / \mathrm{d} l$ \\
\hline $\mathrm{MCH}$ & 31.7 Pg & BS & $79 \mathrm{mg} / \mathrm{d} l$ \\
\hline $\mathrm{MCHC}$ & $34.3 \%$ & CRP & $0.1 \mathrm{mg} / \mathrm{d} l$ \\
\hline Plt & $0.9 \times 10^{4} / \mu l$ & $\mathrm{TP}$ & $5.3 \mathrm{mg} / \mathrm{d} l$ \\
\hline Reticulo & $7 \%$ & & \\
\hline \multicolumn{2}{|c|}{ Coagulation test } & & \\
\hline PT & $15.4 \mathrm{sec}$ & & \\
\hline APTT & $38.8 \mathrm{sec}$ & & \\
\hline $\mathrm{Fib}$ & $50 \mathrm{mg} / \mathrm{d} l$ & & \\
\hline AT-3 & $69 \%$ & & \\
\hline FDP & $87.2 \mu \mathrm{g} / \mathrm{m} l$ & & \\
\hline
\end{tabular}

Case 2.

\begin{tabular}{|c|c|c|c|}
\hline \multicolumn{2}{|c|}{ Peripheral blood } & \multicolumn{2}{|c|}{ Blood chemistry } \\
\hline WBC & $19900 / \mu l$ & T.Bil & $1.48 \mathrm{mg} / \mathrm{d} l$ \\
\hline Myelo & + & AST & $24 \mathrm{U} / \mathrm{l}$ \\
\hline Band & $1 \%$ & ALT & $15 \mathrm{U} / \mathrm{l}$ \\
\hline Seg & $26 \%$ & LDH & $259 \mathrm{U} / \mathrm{l}$ \\
\hline Eo & $1 \%$ & BUN & $13.6 \mathrm{mg} / \mathrm{d} l$ \\
\hline Mo & $9 \%$ & $\mathrm{Cr}$ & $0.29 \mathrm{mg} / \mathrm{d} l$ \\
\hline Ly & $63 \%$ & $\mathrm{Na}$ & $136 \mathrm{mEq} / \mathrm{l}$ \\
\hline $\mathrm{RBC}$ & $3.27 \times 10^{4} / \mu l$ & $\mathrm{~K}$ & $5.5 \mathrm{mEq} / \mathrm{l}$ \\
\hline $\mathrm{Hb}$ & $10.9 \mathrm{~g} / \mathrm{d} l$ & $\mathrm{Cl}$ & $103 \mathrm{mEq} / \mathrm{l}$ \\
\hline $\mathrm{Ht}$ & $32 \%$ & $\mathrm{Ca}$ & $10.5 \mathrm{mg} / \mathrm{d} l$ \\
\hline MCV & $97.9 \mathrm{fl}$ & TP & $6 \mathrm{~g} / \mathrm{d} l$ \\
\hline $\mathrm{MCH}$ & $33.3 \mathrm{Pg}$ & CRP & $0.1 \mathrm{mg} / \mathrm{d} l$ \\
\hline $\mathrm{MCHC}$ & $34 \%$ & & \\
\hline Plt & $2 \times 10^{4} / \mu l$ & & \\
\hline Reticulo & $12.2 \%$ & & \\
\hline \multicolumn{2}{|c|}{ Coagulation test } & & \\
\hline PT & $12.1 \mathrm{sec}$ & & \\
\hline APTT & $31.3 \mathrm{sec}$ & & \\
\hline Fib & $83 \mathrm{mg} / \mathrm{d} l$ & & \\
\hline AT-3 & $122 \%$ & & \\
\hline FDP & $57 \mu \mathrm{g} / \mathrm{m} l$ & & \\
\hline
\end{tabular}

Fib(mg/dl)

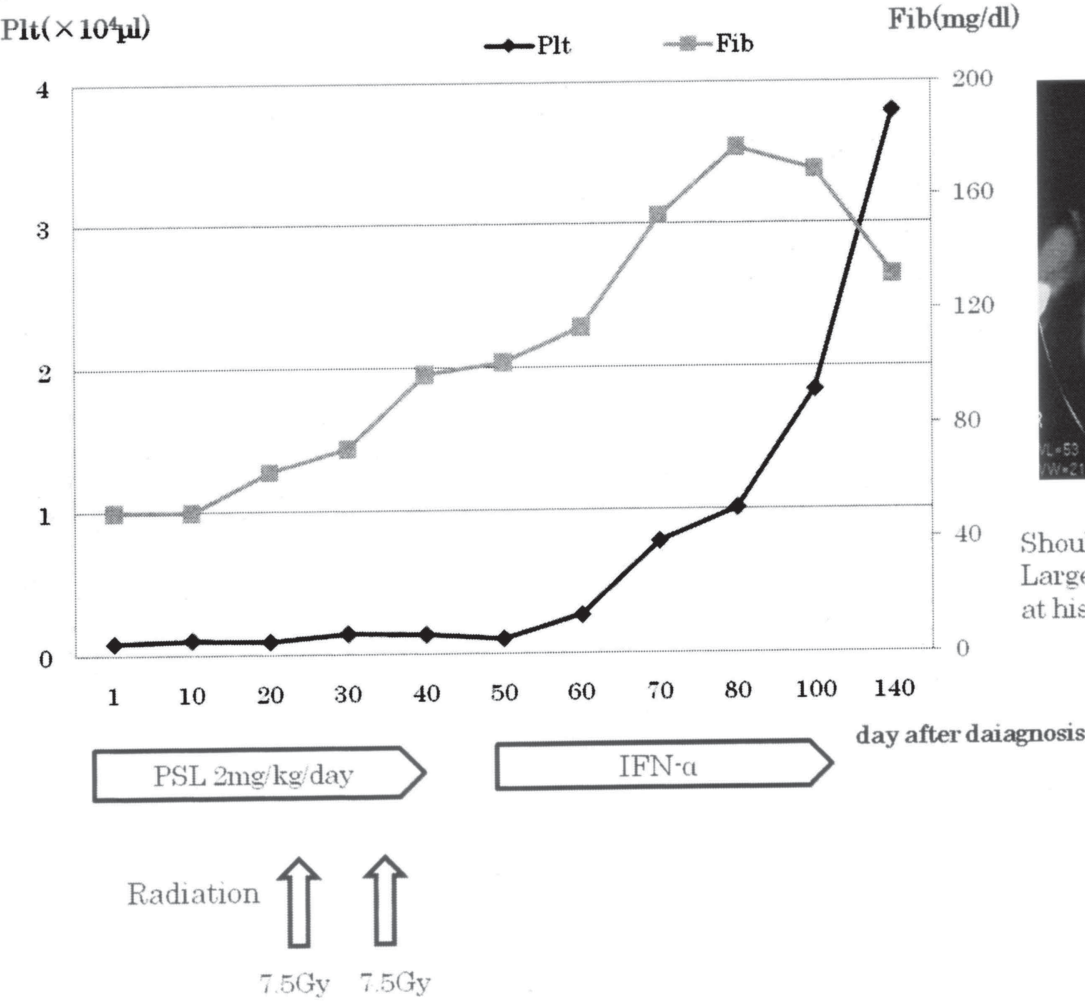

Fig. 1 Shoulder CT scan and clinical course of case 1.

入院後経過 (Fig. 1)：入院翌日から PSL: $2 \mathrm{mg} / \mathrm{kg} /$ 日を 経口投与で開始した . PSL 療法を 2 週間継続したが腫瘤 の縮小効果に乏しく，また血液検査上も血小板数の増 加，凝固異常の改善は認められないため放射線療法を選
択した . 脊椎・肺などを含まないよう腫瘤部位に電子線 $9 \mathrm{MeV}$ を $1.5 \mathrm{~Gy} \times 5$ 日間，総線量 $7.5 \mathrm{~Gy}$ の照射を行っ た . 血小板数の増加や Fib の上昇がみられないため再度 総線量 $7.5 \mathrm{~Gy}$ を追加照射した . 腫瘤の縮小効果は認め 


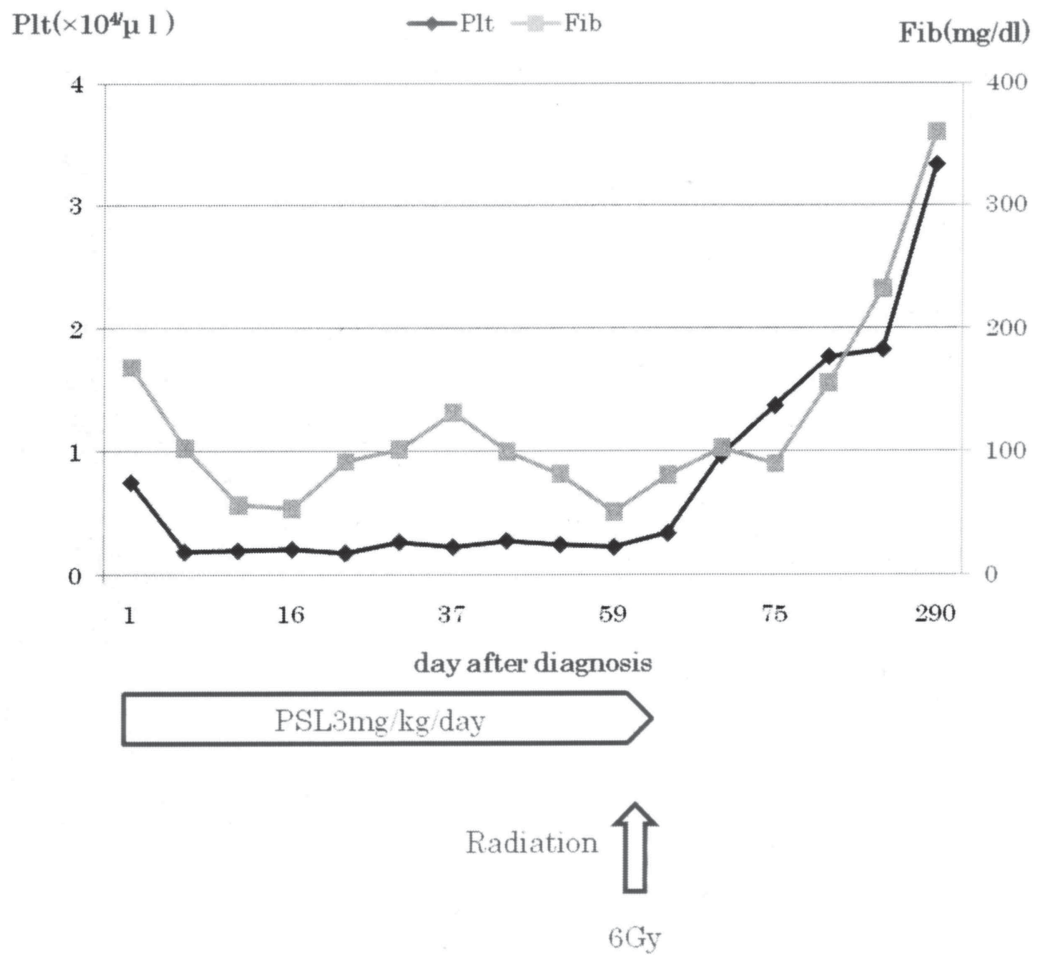

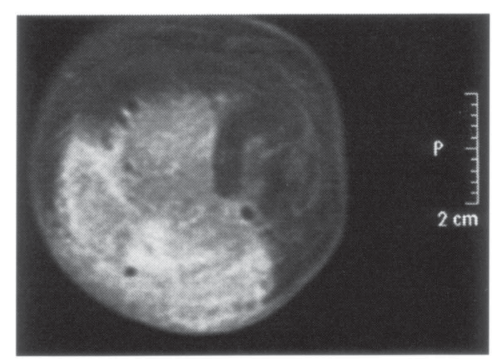

Left arm MRI at diagnosis. Hemangioma had high intensity area and

Fig. 1 Left arm MRI and clinical course of case 2.

られたが血小板数減少と凝固異常は持続した .これ以上 の追加放射線照射は骨および筋の成長障害出現を考え行 わず，IFN $\alpha 300$ 万単位 $/ \mathrm{m}^{2} /$ 回の連日皮下注射を開始し た. IFN $\alpha$ 開始後 2 週目から血小板数の増加を認めるよ うになり, 3 週目には血小板数 $7.5 \times 10^{4} / \mu l$ まで増加を 認めた . 凝固検査もIFN- $\alpha$ の開始時, FDP $51.0 \mu \mathrm{g} / \mathrm{ml}$, Fib $102 \mathrm{mg} / \mathrm{d} l$ であったものが , 3 週目には FDP $6.6 \mu \mathrm{g} /$ $\mathrm{m} l, \mathrm{Fib} 153 \mathrm{mg} / \mathrm{d} l$ と改善を認めた. 光の後 IFN $\alpha$ 療法 8 週目に無熱性痙攣を認めたため, 漸減しながら 10 週目で 投与を中止した . 過去の文献で報告された IFN $\alpha$ 使用中 の痙性対麻疩(認めなかった ${ }^{12)}$. 投与中止後 2 年を経過 しているが腫瘤は消失し, 血液検査上でも血小板数 $39 \times$ $10^{4} / \mu l, \mathrm{Fib} 239 \mathrm{mg} / \mathrm{d} l, \mathrm{FDP} 5.0 \mu \mathrm{g} / \mathrm{ml}$ 末満であり現在まで 再然徴候はない .

症例 2 : 日齢 26 ,男児

主 訴: 左肘血管腫増大

妊娠分婏歴 : 在胎 40 週前期破水のため帝王切開で出 生。

家族歴 : 父方祖父と叔父に肝血管腫がある。

現病歴 : 生直後から左肘に $1 \mathrm{~cm}$ 大の血管腫を認め, 次第に増大するため近医を受診した . 血液検査で血小板 数が $7.0 \times 10^{4} / \mu l$ と減少を認めカサバッハメリット症候 群と診断され経過観察を行っていた，症状が進行し血小 板数が $2.0 \times 104 / \mu l$ になったため PSL $3 \mathrm{mg} / \mathrm{kg} /$ 日を開始 されたが治療効果がなく当院へ転院となった . 転院前に 2 回の血小板輸血と濃厚赤血球の輸血が行われた .

入院時身体所見 : 全身状態良好, 皮膚色は蒼白. 身長
$51 \mathrm{~cm}$, 体重 $4205 \mathrm{~g}$, 体温 $37.5^{\circ} \mathrm{C}$, 心拍 126 回/分, 呼 吸数 36 回/分, 収縮期血圧 $82 \mathrm{mmHg}$,心音は整, 胸骨左 縁下部で Leveine II / VI の収縮期杂倠音を聴取した . 尿道 下裂を認めた . 左肘を中心として上腕から前腕に広がる $6 \mathrm{~cm}$ 大の波動を認める腫瘤を認めた，弚の他の身体所 見に異常を認めなかった .

入院時検査所見 (Table 1)：血液検査は前医での赤血球 輸血後の值である. 血小板数减少と FDPやD ダイマーの 高値，Fib の低値を認めた .

MRI 所見 (Fig. 2) : 上腕背側に $5 \mathrm{~cm}$ 程大の境界不明 瞭な病変を認め, T1/T2 で高信号域を呈し, 造影効果が 認められる . 広がりは上腕二頭筋から骨の周囲に及んで いる .

入院後経過 (Fig. 2) : 前医に引き続いて PSL $3 \mathrm{mg} / \mathrm{kg} /$ 日を 6 週間継続した . 出血の進行はなかったが, 血小板 数と凝固線溶系の改善か認められなかったため, $4 \mathrm{MVX}$ 線 $1.5 \mathrm{~Gy} \times 4$ 回，総線量 $6 \mathrm{~Gy}$ の放射線照射を行った。 照射終了後から血管腫の縮小と血小板数の増加を認め た . 現在 2 年半が経過するが, 触診ではやわらかい部位 をわずかにみとめるのみで外観では左右差はみられな い. 血小板数 $21.4 \times 104 / \mu l$, Fib $163 \mathrm{mg} / \mathrm{d} l, \mathrm{FDP} 5 \mu \mathrm{g} / \mathrm{m} l$ 未満と症状の増悪は認めていない 。

\section{III. 考 案}

カサバッハメリット症候群は巨大血管腫に血小板減 少, 凝固線溶系の異常を合併する病態である . 現在いく つかの治療法が報告されているがいまだ確立された治療 
法はなく，症例ごとに最善と考えられる治療法を選択す る必要がある .これまで報告された治療法にはステロイ ド療法・放射線療法・インターフェロン療法・化学療 法・外科療法などがある.

ステロイド療法は, 通常 PSL の経口投与 ( $2 \sim 3 \mathrm{mg} / \mathrm{kg} /$ day) が用いられる ${ }^{1,2)}$. 重症な有害事象が起こる可能性が 少なく，第 1 選択として通常行われる治療法である. 血 管新生を抑制したりフィブリン溶解を抑制したりして病 变内部の血栓形成を促進する機序が考えられる. 有効率 は30\%程度とする文献が多い2,3) . 高用量のステロイドパ ルス療法の有効性の報告もみられる4) . 有効例では治療 開始後 1 2 週間で血管腫の縮小や凝固異常が改善して いる．しかし有効例でもステロイド減量中の再燃が報告 されており，注意が必要である.自験例ではPSL の使用 では2例ともに血管腫の縮小も血小板数や凝固異常の改 善もみられず, 出血の危険性が続いたため次の治療法を 選択した。

放射線療法は，ステロイド無効例に対して第 2 選択と して選択されることが多く, 通常は 1〜2Gy/回を総線量 3〜9 Gy で行う ${ }^{5 \sim 7)}$. 照射が有効な場合には 10 日以内と 早期に血小板の増加か認められる5). 全身状態が悪化し ているような場合では時期を臆することなく選択をすべ き方法と考えられる．照射野は可能な限り全ての血管腫 を含む範囲とし，同時に可能な限り短期・長期の障害を 避けるように設定しなければならない，骨や性腺・眼 球・肺など主要藏器に対する長期的な障害を考慮し, 総 線量を少なくすることや電子線を選択し周囲組織への照 射を減らすことに努める7). これまでにも四肢の血管腫 で成長障害や筋短縮などの合併症を認めたり ${ }^{5,6)}$, 総線量 $25 \mathrm{~Gy}$ 以上で成長障害を認めたりすることが報告されて いる6). 一回線量を $0.5 〜 1$ Gy の小線量で行い, 総量を 10〜15 Gy 以下までに抑えるべきと考えられている7). 再 照射例では長期的な障害に特に注意が必要である.自験 例では症例 1 では総線量 15 Gy を使用し血管腫の退縮 がみられたが, 血小板数や凝固線溶系には改善がみられ なかった . 現在成長障害や運動障害はみられていない . 症例 2 では総線量 $6 \mathrm{~Gy}$ を使用し血管腫のほぼ完全な退 縮と血小板数や凝固線溶系の改善がみられ，現在まで成 長障害や運動障害は見られていない .

IFN- $\alpha$ は血管の内皮細胞および平滑筋細胞の増殖を抑 制して血管の新生を抑制する効果を期待して血管腫の治 療に使用される ${ }^{1,8)}$. ステロイド療法無効例に選択される が，弚の評価は定まっていない，投与法は 200〜300 万 単位 $/ \mathrm{m}^{2}$ を連日皮下注射か摊奨されている1). 長期投与が 必要であることや痙性両麻痺などの神経学的有害事象の 懸念がある ${ }^{9)}$. 自験例では症例 1 に使用したが , 使用 2 ケ 月めに無熱性痙攣をみとめたため対麻瘦への進行を懸念 して投与を中止している.しかし対麻瘦は認めず，脳波
で左側優位に周波数 $3 \mathrm{~Hz}$ ，振幅 $70-120 \mathrm{mV}$ の spike \& wave を認めたためてんかん発作として抗痙擘薬の内服 を行っている．IFN- $\alpha$ との関連は不明である．血管腫に 対する治療効果は血管腫のほぼ完全な退縮と血小板数や 凝固線溶系の改善を認め, 中止後も再燃はみられていな い.

以上の治療に対しても不応な場合や血管腫の部位的な 問題で放射線照射が不適切な場合には化学療法が選択さ れている ${ }^{1,10)}$. これまでにビンクリスチン $\left(1.5 \mathrm{mg} / \mathrm{m}^{2} /\right.$ 週 $\times 4$ 回/月)やシクロホスファミド $(10 \mathrm{mg} / \mathrm{kg} \times 3$ 日間/月 $)$ で有効性がみられている1) 。 しかし血管腫自体は悪性腫 瘍ではなく，急性期をすぎると自然退縮する可能性もあ る. 化学療法に伴う有害事象や長期障害 (二次癌など) を 考え, 慎重な適応の選択が必要である.自験例では使用 していない．また，血管腫の退縮にプロプラノール $(\beta-$ blocker) が有効であるとの報告がみられ今後の検討が待 たれる11)。

\section{結 語}

カサバッハメリット症候群に対しては, 多数の治療法 の中から全身状態や血管腫の存在部位・出血の重症度な どを考慮して , 症例ごとに最適な方法を選択する必要が あると考えられる .

\section{文献}

1) Hall GW. Kasabach-Merritt syndrome: pathogenesis and management. Br J Haematol 2001; 112: 851-861.

2) 三間屋純一 . Kasabach-Merritt 症候群の病態と治療戦略 . 日小血会誌，2006; 20: 143-149.

3) Enjolras O. Management of alarming hemangiomas in infacy: A review of 25 cases. Pediatrics 1996; 85: 491-498.

4) Sadan N. Treatment of hemangiomas of infants with high dose of prednisone. Pediatr 1996; 128: 141-146.

5) Mitsuhashi N. Outcome of radiation therapy for patients with Kasabach-Merritt syndrome. Int Radiat Oncol Biol Phys 1997; 39: 467-473.

6) Ogino I, Torikai K, Kobayashi S, et al. Radiation therapy for life- or function-threatening infant hemangioma. Radiology 2001; 218: 834-839.

7) 根本健二 . 良性疾患の放射線治療 Kasabach-Merritt 症候 群 . 臨床放射線 , 2002; 47: 104-111.

8) Lopriore E. Diffuse neonatal hemangiomatosis: new views on diagnostic criteria and prognosis. Acta paediatr 1999; 88: $93-$ 97.

9) Grima I, Dureau E, Ejolraso. Effectiveness and dangers of interferon-alpha in the treatment of severe hemangiomas in infants. Arch Pediatr 2000; 7: 163-167.

10) 稲葉三枝 . 治療に難渋し VAC 療法が奏功した腹部巨大血 管腫 (Kasabach-Merritt 症候群) の一例 . 小児がん，2004; 41: 101-106.

11) Léauté-Labrèze $C$. Propranolol for severe hemangiomas of infancy. N ENGL J MED 2008; 358: (24) 2649-2651.

12) Barlow CF, et al. Spastic diplegia as a complication of hemangiomas of infancy. J Pediatr 1998; 132: 527-530. 